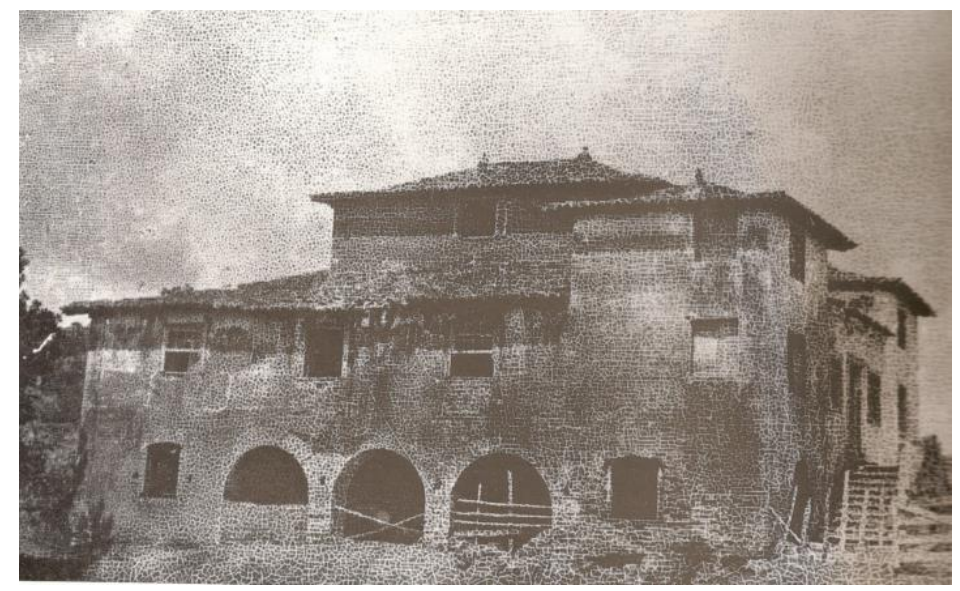

\title{
A memorialística do espaço em Gilberto Freyre, Jayme Griz e Pedro Nava
}

\author{
The memorialistic of space in Gilberto Freyre, Jayme Griz and Pedro Nava
}

\author{
Maria Alice Ribeiro Gabriel ${ }^{1}$ \\ ORCID: https://orcid.org/0000-0003-0256-1306
}

\begin{abstract}
Resumo: Lugares assombrados são usualmente relacionados aos efeitos psíquicos de medos e traumas coletivos. Segundo Michael Mayerfeld Bell, Tim Edensor e Yi-Fu Tuan, os conceitos de lugar e espaço são essenciais para se entender como a memória cultural associada a um lugar opera na criação de relatos legendários, literários e míticos da História. Este estudo examina aspectos históricos, literários e sociológicos da ideia de espaço em memórias públicas e privadas, centrando-se em textos de Gilberto Freyre, Jayme Griz e Pedro Nava. O propósito é expor histórias de fantasmas como representações mentais partilhadas em resposta ao passado, formando um patrimônio cultural complexo que integra possíveis interpretações de um fato ao valor simbólico dos lugares, combinando diversos discursos.
\end{abstract}

Palavras-chave: Lugares assombrados; História literária; Memória.

\begin{abstract}
Haunted places are usually associated with the psychic effects of collective fears and traumas. According to Michael Mayerfeld Bell, Tim Edensor and Yi-Fu Tuan, the concepts of place and space are essential to understand how the cultural memory attached to one place operates in the creation of legendary, literary, and mythical accounts of History. The present study examines historical, literary and sociological aspects of the idea of space in public and private memories, focusing on the works of Gilberto Freyre, Jayme Griz and Pedro Nava. The aim of this paper is to expose that ghost stories are shared mental representations in response to the past and a complex cultural heritage that unites possible interpretations of the meaning of a fact to the symbolic value of places, combining many discourses.
\end{abstract}

Keywords: Haunted places; Literary history; Memory.

\footnotetext{
${ }^{1}$ Doutora em História Social pela Universidade de São Paulo, pesquisadora vinculada ao grupo Variações do Insólito: do mito clássico à modernidade - UFPB/CNPq. E-mail: rgabriel1935@ gmail.com
} 
Um amigo, porém, me adverte de que parece haver uma migração de fantasmas do Norte para o Sul do país como houve outrora de bacharéis e de negros escravos, e há, hoje, de trabalhadores.

Gilberto Freyre, Assombrações do Recife Velho

\section{Introdução}

Conflitos políticos encontram-se frequentemente no cerne de transformações culturais, ecológicas, espaciais e sociais que mobilizam o deslocamento populacional. Diásporas, êxodos e migrações afetam a curto e longo prazo culturas e territórios. Mediado pelas ciências sociais, o estudo geo-histórico do espaço tem alcançado questões de ordem diversa: desterritorialização, globalização, mobilidade, patrimonialização, toponímia e urbanização - questões apreendidas pela literatura e pelas artes através das noções de criatividade, memória e imaginação.

Segundo Alex Mahoudeau (2016), nos anos noventa, pesquisas no campo da Geografia e novos paradigmas sobre o espaço nas Ciências Sociais levaram o estudo sobre mobilização espacial a revisar o problema do espaço na análise de movimentos sociais apresentada em décadas anteriores. Até então, as orientações preponderantes quanto às leis do fenômeno social reduziam-no à espacialidade ou ignoravam-na. Nos anos sessenta, o desinteresse pela relação entre espaço e sociedade vinculou-se ao declínio da "geografia regional" e à evolução epistemológica de uma geografia de cunho positivista, que reduziu o espaço a questões de distância e distribuição, fixando-se no reconhecimento dos efeitos do espaço nessa distribuição. Em resposta, a geografia humana devotou-se mais à teoria social, levando a crítica cultural e literária a buscar na geografia histórica novos enfoques sobre o espaço (MAHOUDEAU, 2016).

A partir de Space and Place: The Perspective of Experience (1977), Landscapes of fear (1979), "Espaço, tempo, lugar: um arcabouço humano" (2011) e Romantic Geography: In Search of the Sublime Landscape (2013), Yi-Fu Tuan aprimorou a discussão sobre temas como: a relação da experiência humana com o espaço; a influência da industrialização, urbanização e do tempo na paisagem; a percepção das noções de espaço e lugar; a constituição do espaço mítico e poético; e o sentimento de segurança, medo e pertencimento a determinados lugares.

Concorde ao estudo de Tuan (1979), Michael Mayerfeld Bell arguiu em "The Ghosts of Place" (1997) que fantasmas, descritos como "[...] the sense of the presence of those who are not physically there", seriam característicos da experiência humana de 
povos modernos e tradicionais, além de um aspecto onipresente da fenomenologia do lugar (BELL, 1997, p. 813).

Em Ghostly Matters: Haunting and Sociological Imagination (1997), Avery F. Gordon notou que muitas histórias sobre visões espectrais têm o papel de recordar fatos pretéritos que não deveriam ser esquecidos, mas não analisou as implicações dos fantasmas por lugar (BELL, 1997, p. 834), como o fez Michele Hanks em Haunted Heritage (2014), ao avaliar a função do espaço na reconfiguração do fato histórico, confirmando e modificando noções dominantes do passado. Gordon expôs ainda a questão da preservação da memória local, ligada ao turismo e à origem de uma classe profissional para investigar lugares supostamente mal-assombrados.

Relacionados à linha de pesquisa adotada por Gordon encontram-se: The Solace of Fierce Landscapes (1998), de Belden C. Lane; Dakota: A Spiritual Geography (2001), de Kathleen Norris; The Open Space of Democracy (2004), de Terry T. Williams; Subterranean Cities (2005) e Metropolis on the Styx (2007), de David L. Pike; e From Mastery to Mystery: A Phenomenological Foundation for an Environmental Ethic (2014), de Bryan E. Bannon, obras que discutem a influência da cultura, ecologia, história, memória, mitografia e simbolização sobre as ideias de espaço, natureza e urbanização presentes nos discursos científico e literário.

Bárbara Misztal, em Theories of Social Remembering (2003), Paul Cohen, em History and Popular Memory (2014) e Martyn Hudson, em Ghosts, Landscapes and Social Memory (2017) analisaram a origem e função de histórias de fantasmas, legendas e mitos para atenuar memórias emocionais de épocas historicamente conturbadas, bem como a importância e o efeito social dessas histórias na preservação da identidade étnica e cultural de comunidades.

Segundo Tim Edensor (2005b, p. 835), a urgência de explorar lugares malassombrados coaduna-se às políticas de rememorar o passado, sobretudo à espacialização da memória e ao modo como memórias evocam e articulam-se ao passado. Nos Estados Unidos, por exemplo, entre os espaços ligados à Guerra Civil, o campo de batalha de Droop Mountain é considerado o lugar a que se relaciona o maior número de histórias de aparições sobrenaturais. De acordo com Rosemary E. Guiley (2024, p. 69-72), em 1928 o local onde sucedeu a batalha foi integrado a um parque estadual seguido da instalação de um museu dois anos depois, com monumentos, túmulos de confederados, artefatos e diversos vestígios arqueológicos relacionados ao conflito. 
O historiador militar Terry Lowry devotou um capítulo inteiro de Last Sleep: The Battle of Droop Mountain (1996) aos fantasmas desse campo. Isolado em uma localidade rural, Droop Mountain tem sido cenário de muitos relatos de aparições sobrenaturais, desde o combate de 6 de novembro de 1863. Cabe notar o interesse de Lowry por consultar não só fontes históricas oficiais sobre a batalha de Droop Mountain, mas também fontes orais, das quais obteve relatos de primeira mão de moradores de propriedades vizinhas ao campo, que descreveram aparições de tropas fantasmagóricas, soldados decapitados e sons de combate ao longe durante a noite.

Lowry (1996, p. 2) chamou atenção para o fato de Droop Mountain apresentar divididos entre ambos os exércitos soldados da mesma região, que já se conheciam ou tinham parentesco. Numerosos pais, filhos, irmãos e primos lutaram uns contra os outros em quase todas as partes do campo de batalha. Certamente a maior parte das reminiscências de testemunhas diretas dessa batalha não foi preservada pelas gerações seguintes ou se restringiu à memória familiar de um grupo. Mas é possível que certas histórias de fantasmas fixadas no contexto da batalha de Droop Moutain permaneçam na memória local. Gilberto Freyre explanou como o espaço pode reativar a memória coletiva sobre eventos do passado por meio de "fatos" "difíceis de ser explicados", mas que se circunscrevem a locais onde houve grandes perdas humanas, como nos exemplos:

Havia na Imbiribeira, além dos Afogados, uma casa que os moradores mais antigos do lugar diziam que era mal-assombrada. Pelo que incumbi em 1929 o repórter policial d'A província de ouvir essa boa gente, moradora de lugar tão sinistro: lugar célebre por fuzilamentos no tempo do Marechal de Ferro. Contaram ao rapaz que ali ocorriam fatos na verdade extraordinários. Difíceis de ser explicados. (FREYRE, 1987, p. 160).

Isso de haver luzes misteriosas nos morros onde houve guerra, aprendi que é crença entre os celtas (...) Descobri crença semelhante entre velhos moradores de Casa-Forte e das imediações do morro do Arraial, no Recife (...) entre os mais velhos - é crença de que aparecem luzinhas misteriosas nos morros onde se travaram encontros da gente luso-brasileira com a flamenga; ou onde a gente luso-brasileira teve seu arraial. Ignoro se continuam a aparecer tais luzinhas. Dizia Josefina Minha-Fé, velha moradora da Casa-Forte e da Casa Amarela, que estava farta de vê-las nas noites de escuro; que eram almas de soldados que haviam morrido lutando; que eram espíritos de guerreiros ali mesmo tombados. Zumbis de campo e não de interior de casa. (FREYRE, 1987, p. 59-60). 
Em Narratives in Social Science Research, Barbara Czarniawska (2004, p. 36), arguiu que toda sociedade possui, em qualquer ponto do tempo, uma série de histórias em circulação sobre fatos que necessitam ser transcritos em narrativas com enredo ou enfocados por meio de uma história remota, atribuindo ao campo prescrito coerência e validação. Todo grupo conserva um repertório de histórias apresentadas aos neófitos como forma de acesso ao grupo, repetidas, se possível, em face de seus atores principais, validando, pela reconstituição da história, a ideia de pertença àquela sociedade. Nesse sentido, Alfred Kubin, Edward Scriven, Henry Fuseli, John Downman, John Everett Millais, Joseph Werner, Richard Riemerschmid, Theodore Chasseriau e William Blake perpetuaram histórias de fantasmas das tradições oral e literária em sua arte.

Considerando aspectos históricos e literários de obras vinculadas à sociologia, literatura e memorialística, este artigo pretende analisar referências a espaços considerados sobrenaturais em Assombrações do Recife Velho (1955), de Gilberto Freyre; O Cara de Fogo (1969), de Jayme Griz; e Baú de Ossos (1972), de Pedro Nava. Nascidos na mesma geração, os três autores coligiram relatos e dados da história local, regional e nacional. São dados históricos procedentes de fontes escritas e orais, mesclados a elementos ficcionais, comentários e reminiscências dos próprios autores. Assim, certo espaço "mal-assombrado" pode ser lembrado simultaneamente por meio de fontes oficiais, do testemunho pessoal ou de casos enraizados na memória coletiva.

Os relatos dos conterrâneos Freyre e Griz se complementam: o primeiro descreveu casos que aludem ao processo de urbanização do Recife na fase de transição do Império para a República; nesse período sucedem os casos de $O$ Cara de Fogo, época em que os senhores de escravos da Zona da Mata pernambucana se fixam nas cidades, tendo vendido terras e engenhos arruinados para emergentes usinas mecanizadas. Os relatos sobrenaturais de Baú de Ossos ocorrem na mesma época, porém em Minas. Tal como Griz, Nava retratou espaços de economia rural e escravocrata e, a exemplo de Freyre, espaços urbanos inóspitos ou em desenvolvimento.

Analisando aspectos históricos, literários e sociológicos da noção de espaço nos relatos de Freyre, Griz e Nava, este artigo pretende discutir histórias de fantasmas como representações do passado, transmitidas por meio de narrativas assentes em memórias pessoais e coletivas. O objetivo é comentar, a partir de estudos de Avery Gordon e Yi-Fu Tuan, como tais relatos unem vários discursos para associar interpretações de fatos marcantes ao valor simbólico dos lugares. 


\section{Três memorialistas de espaços assombrados}

Autores brasileiros contemporâneos de renome, Gilberto Freyre (1900-1987), Jayme de Barros Griz (1900-1981) e Pedro Nava (1903-1984) trouxeram histórias da cultura popular para seus escritos. As narrativas concernentes ao sobrenatural em Assombrações do Recife Velho, O Cara de Fogo e Baú de Ossos apreendem relatos da cultura popular oriundos de fontes diversas da oralidade, porém indicativos de que a memória social é uma das cariátides do vasto edifício da tradição. As três obras apresentam relatos coligidos de fontes orais em algum momento, dado que os autores realizaram estudos nesse campo: Freyre, como sociólogo; Griz, como folclorista e Nava, como memorialista. Os relatos possuem ainda um componente pessoal, proveniente de recordações de infância, lembranças e até mesmo experiências pessoais dos próprios escritores, a exemplo de um episódio referido por Nava em Balão Cativo (1973) e Chão de Ferro (1976):

Fui cúmplice de e cometi no colégio vários crimes perfeitos. (...) Quem? jamais desconfiou do autor das pedradas no sino de bronze do térreo (que víamos das janelas de cima do poço de ventilação) que assim gongava madrugada alta. Pois era eu e só parei a brincadeira na noite em que divisei, embaixo, olhando para mim, um velho majestoso, barbas brancas, olhos muito azuis e sobrecasaca fosforescente. Na hora, bem que pensei que fosse o fantasma de Dom Pedro II. Depois vi que isto era besteira, que aquilo só podia ser o Seu Nélson, entrevisto na escuridão. Há pouco li que os sinos do Internato e do Externato só serviam para anunciar a entrada, na Rua Larga de São Joaquim ou no Campo de São Cristóvão, do patrono da nossa Casa. Tive um arrepio retrospectivo: eu tinha visto, claramente vista e invocada por mim, a Sombra Augusta do Imperador. (NAVA, 1977, p. 328).

Tudo dormia - colegas, Salatiel, Pires Ventania. Pé ante pé eu saía, experimentava meu pavor nas barrancas da escadaria - que súbito vórtice parafusava em trevas abissais. Ia debruçar no abismo do Poço de Ventilação. Embaixo, o sino de bronze. Foi quando tive a ideia de fazê-lo mugir a pedrada e disso resultou (já o contei no meu Balão Cativo) ver aparecer, lá embaixo, a Sombra Augusta de Dom Pedro. Até que nessa noite voltei tiritando para minha cama, dormi, tive o sonho da escada e no dia seguinte fui internado na Enfermaria todo eriçado e pegando fogo. (...) Como foram tantos! tantos! Meus pervagares no dormitório... (NAVA, 1976, p. 61).

Da aparição do "fantasma de Dom Pedro II" emergem, como por planos consecutivos e superpostos: a história do célebre Colégio, a função dos "sinos do 
Internato e do Externato", o retrato de parte das ruas antigas e do complexo arquitetônico da Zona Norte do Rio do Janeiro, e costumes remanescentes do Segundo Reinado que permitem ao leitor vislumbrar uma cidade já inexistente, acessível apenas pela literatura, memorialística, historiografia e crônica histórica.

Tomando de empréstimo as palavras de Alfredo e Afonso de Escragnolle Taunay (1932, p. 37), “[...] a lembrança augusta do Sr. Pedro II, perpetuando tradições que não morrem, nem podem morrer", sugere nesse episódio das Memórias o aspecto evanescente da interpretação do registro histórico de cada época. Relatos sobrenaturais interpretam e transmitem a memória histórica local. A reputação de mal-assombrado confere ao lugar certa mensagem cultural e as narrativas que a veiculam podem ser pensadas na acepção de uma história oral particularizada.

Freyre (1987, p. 8) transcreveu a história dos sobrados e logradouros malassombrados da capital pernambucana "[...] para o estudo de um aspecto meio esquecido do passado recifense: aquele em que esse passado se apresenta tocado pelo sobrenatural. Pelo sobrenatural mais folclórico que erudito, sem exclusão, entretanto, do erudito". Perpetuadas na literatura oral e na escrita, as histórias de locais mal-assombrados subsistem em períodos e locais específicos, devido ao impacto cultural e histórico que um evento alcançou para repercutir entre gerações.

Assim, as "visagens" das histórias reunidas por Freyre: o Boca-de-Ouro; o "lobisomem doutor" de sobrado do Poço da Panela; as luzes misteriosas nos morros; "o fantasma de Branca Dias"; as "moças nuas no meio das águas da Prata"; os coches misteriosos que transitam à meia-noite, à semelhança do "[...] que há anos levara ao cemitério de Santo Amaro certo titular do Império"; almas de afogados, de suicidas, de "criminosos arrependidos de seus crimes"; o "homem de sobrado" tornado Papa-Figo; viscondes e barões encantados e assassinados ou até perseguidos pelo diabo; "o próprio Espírito das Trevas"; senhores "de terras fecundadas não só com suor como também com sangue de negro" "e fantasma também de inglês, todo de dólmã branco, sapatos como os dos ingleses jogarem tênis" são aparições que o autor preferiu definir:

[...] em ambientes e em circunstâncias próprias do Recife: os de sua condição de cidade não só situada à beira mar como cortada por dois rios; de burgo por algum tempo judaico-holandês e não apenas ibero-católico; de capital de província e de estado depois de ter sido simples povoação de pescadores; de sede de vários conventos; de centro de atividades culturais importantes; de 
grande mercado de escravos trazidos da África; de espaço urbano caracterizado por sobrados de tipo esguio, de feitio mais nórdico do que ibérico: provável influência holandesa ou norte-europeia sobre sua arquitetura. (FREYRE, 1987, p. 8).

Se as assombrações descritas por Freyre refletem aspectos particulares da arquitetura, colonização, folclore, economia, história, mitografia, organização social, política, religiosidade e toponímia da capital pernambucana, os "malassombros" de $O$ Cara de Fogo são expressões desses mesmos aspectos, centrados porém nos "ambientes e circunstâncias próprias" da região canavieira da Zona da Mata de Pernambuco. Ainda que reportem a eventos trágicos e violentos, situações de abandono, assassinato, discriminação, suicídio, transgressão de leis sociais e das que regem as relações do homem com a natureza, as assombrações de Griz constituem, além de histórias sobre experiências individuais traumáticas, o retrato de um modelo socioeconômico que expirou gradativamente com a crise do açúcar e as políticas abolicionistas do século XIX.

Nas palavras do contador de histórias de "O fantasma negro do bueiro da usina Cucaú”, Griz (1969, p. 93) delimitou esse modelo com precisão, situando-o: “[...] desde antes do banguê até a botada da usina, aí pelos fins do século passado”. Considerando-se esse paradigma, certos espaços de $O$ Cara de Fogo são assombrados pela ruína de antigos engenhos, os que tiveram

[...] as crises. As doenças da cana. O açúcar de outras terras atrapalhando o nosso (...) casa-grande de tijolo e cal e uma capela onde um padre, nos bons tempos, rezava missa num domingo de cada mês, viajando de liteira do engenho (...) crise de braços e de trabalho com o desmantelo trazido pela libertação dos negros (...) E essas duas histórias, seu moço, vêm a ser depois uma só: A que fala dos banguês de ontem e das usinas de hoje. Do banguê a vapor foi um salto p'ro meio-aparelho e o engenho-central, ou usina, que o Governo desse tempo ajudou com auxílio a se desenvolver, visando melhorar o processo de moagem e de fabricação de açúcar. Isso vale como parte da história do açúcar na nossa terra (...) Pra não ir muito longe, eu vou dizer por cima o que foi essa coisa no passado. Não foi nem mais nem menos do que a passagem da era do banguê pra era da usina. (GRIZ, 1969, p. 95-99).

Engenhos históricos, tais como Aratinga, Barbalho, Camivou, Cocaupe (Usina Cucaú), Gigante, Gravatá e Liberdade, com casa de moagem, casa de farinha, "botija com dinheiro de defunto", "dinheiro enterrado na casa-grande do engenho ou na capela", estribaria, liteira para as viagens da Sinhá, “mão-de-pilão batendo na peça de pilar” e 
"velha casa-grande", povoados cercados de pequenos sítios, em que aguardenteiros, barraqueiros, cambiteiros, cargueiros, carpinas, carreiros, comboeiros, destiladores, escravos, estribeiros, farinheiros, fornalheiros, negociantes de rapadura, mestres de açúcar, moendeiros, mucamas, sentinelas e vigias cultivavam "roçados de milho, feijão e mandioca”, "[...] até que o senhor de engenho, atormentado pelas constantes crises do açúcar, cansaço de suas terras e declínio crescente dos banguês com o advento das Usinas, vendeu sua velha propriedade, ausentando-se da região, deixando [o engenho] (...) de fogo-morto" são os espaços mais referidos por Griz (1969, p. 69).

As assombrações dos contos de Griz (1969, p. 97) surgem com: “[...] a derrubada de velhas construções do engenho: estribarias, senzala, destilaria, casa de moagem, isso depois de retirada a ferragem: tachas, moendas, fôrmas de purgação de açúcar, caldeira do vapor, etc.”, sempre reavivando a memória do espaço em que são vistas: o fantasma da Conha, "no abandono e no êrmo do seu sítio"; o fantasma do maquinista, na estrada onde "um trem de carga virou na Volta dos Bambus"; o fantasma da mata do Chareta, no local do enforcamento; "a assombração da usina”, no bueiro do engenho Cucaú; a "abusão de João-Perdido", nas matas do Mearim; e o cavalo fantasma, "na estrada do engenho Barbalho". Segundo um dos narradores de Griz:

Os senhores de terras e de escravos, muitos deles morreram de raiva e de desgosto. Uns sumiram do lugar, pra longe. Outros emperraram no orgulho da riqueza passada e não arredaram o pé de suas terras e casas-grandes. Escondidos e acuados como bichos dentro dos casarões, dava que falar ao povo aquele jeito de viver de gente rica e luxenta desse tempo. Depois veio a era das usinas para acabar de vez com a soberba desses senhores de ontem. Mas muitos desses senhores não venderam suas riquezas de terras e casas-grandes, não. Nelas ficaram e muitos deles nelas morreram. $\mathrm{E}$ foi esse o caso do senhor do sobrado [que] (...) virou malassombrado. (GRIZ, 1969, p. 167-168).

"Vários desses sobrados ganharam fama de mal-assombrados", segundo Freyre (1987, p. 8), bem como "A casa-grande cheia de molecas e negras para os serviços de Sinhá. Cheia de Sinhazinhas e Sinhozinhos" citada por Griz (1969, p. 65). Vestígios de uma era de opulência, quando esses espaços se tornam ruínas na faixa do perímetro urbano, a história de uma aparição pode associar certa memória à paisagem, como sugeriu Freyre (1987, p. 36): "Mal-assombrado ainda mais romântico é o que por muito tempo animou o escuro das noites recifenses defronte da antiga casa-grande do sítio de Bento 
José da Costa, da qual só resta hoje a capela". O espaço da casa-grande nos contos de Griz recorda uma sociedade de costumes quase feudais em que

[...] os senhores de engenho e de terras de coqueiros e de outras riquezas, tinham suas casas-grandes nas terras de plantar e também (...) na cidade. E (...) viviam esses senhores vida boa e da melhor, sem faltar nada. Dinheiro a bambão e negro escravo pra trabalhar e sofrer. Luxo, passeio, fartura, e alegria muita de senhores ricos era o que se via. (GRIZ, 1969, p. 167).

Um correlativo do senhor de escravos, engenhos e terras que, acastelado em seu sobrado, se torna abusão em $O$ Cara de Fogo seria o protagonista de "Um barão perseguido pelo diabo", assim descrito por Freyre (1987, p. 87): "Vinha o barão ao Recife e aqui vivia como qualquer outro lorde pernambucano da época, vida alegre e descuidada. Jantava no Torres. Divertia-se no teatro vendo as cômicas. Ia afofado em carro de luxo às corridas do Piranga". Ao prefaciar a 4. a edição de Assombrações do Recife Velho, José Geraldo Nogueira Moutinho destacou um aspecto da obra que incide na representação simultânea da localidade, da região e da nação:

Assim como a aristocracia propiciou a Proust o abismo em que pôde
mergulhar na alma humana, a casa-grande propiciou a Freyre a porta do
labirinto em que surpreendeu o ethos e o pathos de nossa maneira de
ser no mundo (...) Em nossa literatura, estas páginas gilbertianas
encontram-se ao lado de certas outras deixadas por Cornélio Pena em $A$
menina morta, ou daquelas, evocadoras das apavorantes assombrações
mineiras, incluídas por Pedro Nava em suas Memórias imortais.
(MOUTINHO, 1987, p. 22-24).

Os aspectos históricos e memorialísticos assentes nos espaços sobrenaturais dos textos de Freyre, Griz e Nava, descontado o estilo particular de cada autor, possuem uma característica comum às literaturas romântica e simbolista, que exploraram o efeito de onirismo na descrição de ambientes. Assim, engenhos, casas-grandes e sobrados arruinados pelo abandono, ação do tempo; sítios insólitos, "o zumbi do boi morto" e "os gritos dos fantasmas da mata" são parte da "terra de abusão", que recorda nos contos de Griz (1969, p. 26) imagens das Pinturas Negras de Goya: “Que aquilo era um mundo do outro mundo (...) Mundo de sombras e fantasmas”.

As ruínas e a natureza não formam um quadro bucólico quando descritos por Griz (1969, p. 23), a exemplo do sítio "com fama de malassombrado": "A casa da moradia ficava num alto, numa meia banda de córrego. Tinha paredes de taipa e coberta de sapé. Pelo abandono em que vivia estava arruinada e cercada de mato". "O Sítio da Conha", 
"O Cara de Fogo", "A enforcada da Mata do Chareta", "João perdido", "O cavalo fantasma da estrada do engenho Barbalho" e "Assombrações no Rio Formoso" são histórias em que espaços ermos e desoladores prenunciam aparições sobrenaturais, ocasionando experiências e memórias atípicas para as personagens.

A relação entre história e memória é essencial em $O$ Cara de Fogo, sobretudo nos contos em que um personagem, na função de narrador da oralidade, é capaz de reconhecer e elucidar as experiências sobrenaturais vividas por outrem por ser conhecedor das histórias do passado. Griz (1969, p. 95-97) sempre permite a este narrador delimitar o contexto em que se originou a aparição, por exemplo: "Depois de 88 e das crises que vinham abalando os engenhos e seus senhores"; e os ambientes que a identificam com esse contexto, no caso do fantasma da usina Cucaú: "velhas construções do engenho: estribarias, senzala, destilaria, casa de moagem". Pela descrição dos ofícios dos personagens e da história desses espaços, o autor esboça, igualmente, uma identidade regional para cidades da Zona da Mata dependentes da economia açucareira:

No passado, ali floresceu uma aristocracia de senhores rurais. Senhores de engenho. Senhores de terras e de vastos coqueirais. Senhores de outras tantas riquezas que as fecundas terras do velho município propiciavam. Ainda hoje a cidade tem evidentes sinais dêsse seu passado de riqueza e fartura. Velhas residências senhoriais dizem bem ainda dos contatos desses antigos senhores de terras com o velho burgo. (GRIZ, 1969, p. 158).

Embora descreva localidades em desenvolvimento, como Palmares e Custódia, Griz (1969, p. 51) atribui sentido distópico à “[...] velha cidade sertaneja, cuja história está cheia de episódios terríveis, de cenas aterradoras, de lutas por velhas intrigas de famílias e de assaltos de cangaceiros". O vendedor ambulante de "Assombração no Rio Formoso" percorre "velhas praças ou logradouros mal cuidados ou abandonados ao descaso público" do "antigo burgo do Rio Formoso", onde irá pernoitar em um "velho sobrado abandonado": "Era um velho edifício do século passado, de dois pavimentos e um amplo sótão com janelas para os oitões. (...) Tudo ali estava abandonado, sujo, velho, carcomido pelo tempo e roído pelos ratos (...) cheio de sombras, de evocações, de memórias de seus antigos senhores" (GRIZ, 1969, p. 163-164).

Caminhos isolados, campos de batalha, casas abandonadas, ruínas e até mesmo florestas podem estar impregnadas de memórias nos relatos sobrenaturais de Freyre, Griz e Nava. Com referências históricas e sociais, a lembrança do passado por meio do raconto sobre um fantasma reporta, segundo Freyre $(1987$, p. 11) a “'sociedades' de que seria 
possível fazer-se o estudo sociológico"; contribui para a criação de uma geografia ficcional sobre o pós-abolição na obra de Griz; e conduz a narrativas populares do "Norte, Sul, Mata, Triângulo, Centro" da "Minas abstrata" de Nava (1974, p. 105), com: "Os mesmos oratórios de três faces com o calvário em cima e o presépio em baixo. Os mesmos registros de santos enchendo as paredes para impedir os mesmos demônios e as mesmas avantesmas da noite de Minas. As visagens-lares e do teto".

No excerto biográfico que narra a jornada dos bisavós maternos de Nava, com parentes e escravos, "do Centro para a Mata", o memorialista cita usos, costumes e tradições religiosas (“em Congonhas, um rosário em cada passo, um terço aos pés de cada profeta”). Para contar a história da abertura do Caminho Novo, Nava (1974, p. 127) refere crimes diversos envolvendo "[...] desde os gatunos mesmo até os senhores do solo que, ostensivamente ou à socapa, fizeram reviver nas Minas dos séculos XVIII e XIX o direito feudal do pedaticum", que espoliavam os viajantes. Temido por tropeiros e moradores da região de Barbacena, o Alto do Cangalheiro surge na memória popular como espaço sobrenatural, epicentro das mortes e abusos cometidos no Caminho Novo. O local é mencionado novamente em Balão Cativo, para contar o acidente de trem na viagem de mudança dos Nava, de Juiz de Fora para Belo Horizonte, em fins de 1913:

A travessia do Alto do Cangalheiro à tardinha, com pés de pau estalando como uma conversa, o hurlyburly como na charneca inglesa, um vento alto que parecia desfraldar mortalhas no céu e a estrada movediça, dirse-ia viva e se sacudindo como um lombo de anta... Todos acompanhando Dona Mariana Carolina, que rezava alto as orações fortes de combate às forças do Inferno. (NAVA, 1974, p. 125-126).

Meu avô, que saíra em busca de informações, voltou dizendo que estávamos encostados na Barbacena, pertíssimo do Alto do Cangalheiro. A essa indicação, tia Berta e minha Mãe persignaram-se. O lugar não era dos melhores para passar a noite. De fato, na medida que esta caía e se adensava, começou a vir daquela elevação malassombrada como que um riso e um sussurro. (NAVA, 1977, p. 83-84).

No conto "O Cara de Fogo", um barraqueiro que vende seus produtos em feiras da região tem de passar à noite por um trecho da estrada de ferro conhecido por "Volta dos Bambus". À semelhança do Alto do Cangalheiro, o lugar é considerado malassombrado pelo "povo" e pela "tradição". Assim como Nava, Griz inclui sons misteriosos, vozes e risos na caracterização do espaço sobrenatural em "A enforcada da mata do Chareta", "João perdido" e "Os caititus das matas do Engenho Gigante". Nessas 
histórias, os protagonistas são penalizados por transgredir as leis do espaço sobrenatural ${ }^{2}$, ao percorrer o local mal-assombrado sozinho à noite ou caçar na "sexta-feira, dia de caipora andar solta na mata”. A magnitude do sagrado, que seria possível depreender a partir da mensagem de seus símbolos ${ }^{3}$, determina a gravidade da transgressão:

Todos nós, mineiros, sabemos disto. Conforme o lugar arrotamos bravura como o Doutor Augusto de Lima que era acadêmico de cabeça fria e deputado de espírito forte - isto de dia, na Casa de Machado de Assis ou nas sessões do Parlamento. Não naquele lusco-fusco em que ele se viu, naquela Quaresma, naquele Alto do Cangalheiro, com vento mau e montado em burro preto querendo empacar. Foi quando the apareceu a forma indistinta, fina e grossa, da coisa branca - que ele afrouxou em cima da montaria e o medo imenso ainda cresceu quando ela, a negra, a peluda, a infernal montaria cuspiu o bridão e falou: "Não é nada não, doutor, é lua-nova batendo em folha de embaúba..." Rolando da alimária, o corpo do poeta, como o de Dante ${ }^{4}$, caiu como um corpo morto cai. (NAVA, 1974, p. 105-106).

Aludir a figuras históricas, ao domínio das letras e das artes é recurso que filia os relatos de Nava e Freyre a uma prosa ensaística e linha de reflexão afins à memorialística e à História cultural. Freyre (1987, p. 13) define a contribuição de Assombrações do Recife velho como: "Uma ou outra achega à história íntima da cidade do Recife, cujo ambiente está tão impregnado de assombração (...) Não é de hoje que o assunto interessa o autor". Nesse sentido, Freyre (1987, p. 11) admite que as histórias de fantasmas incluídas na obra seriam: "Quase todas recolhidas diretamente de boas fontes orais", princípio válido para os casos sobrenaturais de Baú de Ossos:

Era o Dr. Bernardino de Lima, irmão do Poeta Augusto de Lima, professor da Faculdade de Direito (...) Tratei logo de renovar conhecimento e fui recebido na casa agradável e simples dessa querida família. Eu devia ser um chato de botas (tinha consciência

\footnotetext{
2 Na classificação de Stith Thompson (1977) para os motivos presentes em narrativas folclóricas, esses contos de Griz reportam à categoria $\mathrm{C}$, relativa aos tabus, com os seguintes motivos: $\mathrm{C} 0$, alusivo ao tabu do contato com entes sobrenaturais e C610, situação em que se infringe a proibição do acesso ao local sagrado ou interdito. Na categoria E, que inclui fantasmas e almas que retornam, sobressai o motivo E200, sobre o nefasto retorno do morto.

${ }^{3}$ De acordo com Peter Brown (1975, p. 8), o papel do sobrenatural em uma sociedade é parte de seu estilo de vida. E o amálgama entre as categorias do sagrado e do profano está saturado de valores projetados por essa sociedade.

${ }^{4}$ Não se observa aqui total proscrição das fontes eruditas (como a referência ao episódio da mula do profeta Balaão, em Números 22: 31-33, e ao Canto V da Divina Comédia), por vezes favoráveis à mais adequada expressão do pensamento do autor; o que se verifica é que Nava não as utiliza abusivamente, nem delas faz uso sistemático com omissão da forma coloquial, ou de recursos estilísticos como a gradação ("a negra, a peluda, a infernal montaria"), a fim de atribuir maior fluidez à narrativa.
} 
disso!) mas era mais forte do que eu: não saía de lá, de dia, de noite, ouvindo as histórias de assombração de Dona Ester e do Manuelito. (NAVA, 1976, p. 112).

Tais considerações são necessárias ao se investigar como os casos redigidos por Freyre, Griz e Nava transcrevem a memória coletiva sobre os espaços sobrenaturais, sem prescindir de outros enfoques ao reproduzir o acervo de histórias de fantasmas difundido em certa região.

\section{Lugares de transição}

Citando Yi-Fu Tuan, Dave Kuhne (1999, p. ix-x) notou que a atitude para com um lugar não é fixa. O que uma cultura teme, outra reverencia: a floresta úmida do Congo, amedrontadora para exploradores europeus, inspira segurança ao pigmeu Mbuti. Entretanto, em $O$ mundo se despedaça (1958), o novelista nigeriano Chinua Achebe descreve a floresta como aterrorizante domínio de maus espíritos. O que gera medo em certo tempo e lugar pode ser reconfortante em outro local e data. Para o europeu primitivo, montanhas e florestas densas eram ameaçadoras (Tuan, 1979), já o colonizador americano via a floresta "as the enemy... the habitat of the godless indian" (Schama, 1995, p. 191 in Kuhne, 1999, p. x). Após o Romantismo europeu, as mesmas montanhas e florestas tornaram-se locais de contemplação da natureza, inspiradores de valores nobres. Para o ocidental da era pós-romântica, o campo era bom e saudável (Tuan, 1979, p. 131), porém muitas novelas americanas ambientadas na África equalizam o espaço aberto com o perigo e a luta pela sobrevivência. Na África, em oposição à Europa e América, paz e segurança não são encontradas no campo, mas nas cidades, fazendas e povoações (Kuhne, 1999, p. x). Em Baú de Ossos, oposta à urbe, a fazenda é o lugar onde se manifesta o desconhecido:

O Doutor Francisco Luís da Silva Campos, o mesmo e insigne ministro da ditadura, todo nietzcheano como ele era - libertado no mundo pela vontade, dionisíaco e apolíneo - disse-me que no Rio, em Copacabana, ele não acreditava em nada, absolutamente em nada. Mas na noite mineira e na fazenda familiar do Hindustão, tinha "medo que lhe aparecesse um trem..." (NAVA, 1974, p. 107, ênfase do autor).

Em "O Cara de Fogo", a "Volta dos Bambus" "era lugar ermo e malassombrado" e no conto "A enforcada da Mata do Chareta", o espaço é definido de modo análogo por Griz (1969, p. 83): “Além dos assaltos de criminosos que por vezes infestavam aquele 
escuro mundo, havia, ainda, a tradição das abusões", lugares que recordam o Alto do Cangalheiro descrito por Nava.

É comum lugares "ermos" adquirirem conotação sobrenatural no imaginário popular, sobretudo se a memória coletiva associou-os a eventos trágicos. A desaparição de alguém, notavelmente se for ilustre ou conhecido, favorece a transposição do fato em história, da história em mito e deste em ser de sonho, fábula e lenda. Conforme Rostand Medeiros (2014), no caso do aviador Pierre Saint-Roman (1891-1927) e da aeronave "Paris-Amérique-Latine": “[...] percebe-se lendo os jornais da época que Natal sentiu o desaparecimento do avião francês".

Segundo Tuan (1979, p. 207) e Kuhne (1999), paisagens amplas e indefinidas geram medo e ansiedade. Fronteiras são estabelecidas justamente para proteger as pessoas do que está fora de seu círculo de controle. Para os ocidentais, regiões vastas e indefinidas como as florestas do Congo, os desertos do Sahara e Kalahari figurariam ameaçadoras, sinistras e misteriosas. Planícies desérticas, florestas e mares são representações usuais do inconsciente na literatura e a história d' "O visconde encantado", relatada por Freyre correlaciona os três espaços.

Em abril de 1927, conta Medeiros (2014), enquanto Natal esperava ansiosamente “o brasileiríssimo Jahú”, foi noticiado outro voo programado para chegar a cidade: “[...] a nave viria pilotada por um nobre francês: o capitão Pierre Serre de Saint-Roman, filho do Conde de Saint-Roman e sua ideia era vir à América do Sul para percorrer 52 cidades do continente e a primeira seria Natal". Freyre (1987, p. 139) descreveu-o como: “Um visconde de romance de capa-e-espada tornado aviador moderno na primeira fase heroica da aviação". No entanto:

Os momentos iniciais do voo de Saint-Roman foram atribulados. Talvez por ele possuir apenas 250 horas de voo como experiência anterior a um salto sobre o Atlântico. Talvez pelo seu avião Farman F.60 Goliath, um biplano bimotor, batizado como "Paris-AmériqueLatine" e concebido originalmente como bombardeiro, não ser a nave ideal. Em todo caso, ele e mais dois companheiros decolam de SaintLouis (Senegal), no dia 5 de maio de 1927, às seis da manhã. Em Natal muitos imaginam que Saint-Roman vai chegar primeiro que o "Jahú", mas o "Paris-Amérique-Latine" e seus tripulantes jamais foram vistos novamente. Somente no dia 29 de junho, restos do avião de SaintRoman foram encontrados entre o Maranhão e Pará, bem distantes da rota planejada pelos aviadores desaparecidos. (MEDEIROS, 2014).

Conforme Jean-Pierre Suzzoni (s/d), possíveis destroços do "Paris-AmériqueLatine" foram achados no litoral do Pará, a 90 quilômetros de Belém: uma pequena balsa 
improvisada, feita de parte da asa ou cauda do avião, duas rodas e uma placa de alumínio atados com cordas. Galleyrand, mecânico especializado da Farman, foi enviado ao local e reconheceu os vestígios como sendo do avião de Saint-Roman. Para o diretor do Museu do $\mathrm{Ar}$ e do Espaço, onde estão as peças, a aterrissagem teria ocorrido entre Natal e Fortaleza, na maré baixa, em praia com falésias de 20 a 40 metros de altura, impossíveis de escalar e que submergem na maré alta.

No caso do "Paris-Amérique-Latine", não só as peças feitas artefatos de museu são itens remanescentes de um momento específico de uma cultura: os primeiros voos experimentais de travessia sobre o Atlântico, realizada, em 1927, por Ribeiro de Barros e Newton Braga no avião "Jaú", atualmente acervo do Museu Ipiranga, mas também a versão histórica oficial do fato, bem como aquelas da cultura popular. A legenda do evento trágico pode ou não seguir objetos relacionados ao fato, como é provável ser desconhecida em França a história do "Visconde encantado", mas quase sempre persiste associada à memória do local, notavelmente se este já possuía uma reputação anterior e conteúdo simbólico cultural favorável à criação de mitos. ${ }^{5}$

A história de Pierre Serre de Saint-Roman abrange as paisagens citadas por Tuan (1979) e Kuhne (1999) como espaços de medo e ansiedade. Dentre tais regiões inóspitas, Tuan (2013, p. 53) destaca o mar, expondo que, em Gênesis 1, relato bíblico da criação, Deus claramente favoreceu a terra, destinando-lhe o Jardim do Éden e suas mais finas criaturas: Adão e Eva. Às águas couberam os "cardumes de seres viventes" e "monstros marinhos", feito o Leviatã. De certo modo, o oceano permaneceu fora do domínio divino. Até o século XX, na imaginação romântica, o mar simbolizou o fluxo primordial, indiferenciado, um estado de bárbara incerteza e desordem, fora do qual a civilização poderia emergir, mas ao qual ela sempre poderia retornar.

Concepções culturais geram atitudes positivas ou negativas para com formas simbólicas específicas, observou Blasco José Sobrinho (2001). Para Carl Gustav Jung, lagos, mares, rios e todas as "tipificações" da água representam a irracionalidade do inconsciente, cujo símbolo favorito seria o oceano: "the sea is the favorite symbol for the unconscious" (JUNG, 1969, p. 177 apud Sobrinho, 2001, p. 22). Freyre narrou o

\footnotetext{
${ }^{5}$ Em "Fact and Fiction in a Legend" (2008), Trefor Doloughan Vaughan fornece um exemplo histórico de um espaço privado criador de mitos ao discutir uma das mais famosas histórias de fantasmas da Irlanda, "The Gill Hall Ghost Story" ou "The Tyrone Ghost Story". Devido ao "status" social dos personagens, nomes e datas podem ser determinados. A legenda tornou-se conhecida desde o século XVII, vinculandose, por gerações, à crônica familiar dos envolvidos. O espaço onde se localizava a propriedade e objetos diretamente relacionados ao fato têm papel preponderante na história e criação da legenda.
} 
desaparecimento do aviador relacionando as áreas de desmatamento, as "matas tropicais" e "águas do Atlântico" a espaços fantasmagóricos:

No fim do governo Estácio Coimbra, foi esperado toda uma noite no Recife - esperado até de madrugada, até o dia seguinte, durante uma semana, um mês - o Visconde de Saint-Roman. (...) Já quase mortas essas esperanças, o Governador (...) recebeu da velha mãe de SaintRoman comovente carta. Fora ela a uma sessão de espiritismo em Paris e aí lhe fora dito que o filho estava vivo: descera em matas tropicais de Pernambuco. Para atender ao clamor da mãe francesa o governador do Estado de Pernambuco ordenou novas buscas em áreas pernambucanas que pudessem ser descritas como de florestas: na verdade, de restos de grandes matas. De fantasmas de matas. (...) O espírito se enganara: o visconde caíra não em matas tropicais do Brasil, mas em águas do Atlântico. Caíra no mar sem ter conseguido chegar ao Recife. Entretanto há recifenses que juram já terem ouvido, em noites altas e de muito silêncio misteriosos roncos de um avião fantasma que não desce nunca: volta ao mar. Será do visconde encantado? (FREYRE, 1987, p. 139-140).

As "águas do Atlântico" ilustrariam o espaço de indeterminação a que o avião fantasma, imagem da civilização, deve retornar, como expôs Tuan (2013, p. 53) aludindo à imaginação romântica, personificada no relato pelos "recifenses" "em noites altas e de muito silêncio".

Segundo William Robertson Smith (1995, p. 123), a natureza do jinn - espírito capaz de assumir forma humana ou animal para inspirar boas ou más ações - ajuda a entender porque certos espaços são relacionados a assombrações. Na vasta solidão do deserto da Arábia, cada som estranho é logo tomado pelo murmúrio de um jinn e cada sinal inusitado por uma aparição demoníaca. No entanto, quando determinados locais foram previamente reconhecidos como mal-assombrados, deve-se supor que os sinais e sons julgados sobrenaturais eram de fato mais frequentes ali do que em outra parte. A reputação sobrenatural de um lugar pode ser alimentada por meras fantasias que, no entanto, exigiram da imaginação algum ponto de contato com a realidade. Assim, em certas áreas do Recife, "em noites altas e de muito silêncio misteriosos roncos de um avião" sobrevoando a costa teriam consolidado a legenda do aviador "encantado".

Embora o jinn habite locais devastados e desertos, suas aparições especiais encontram-se justo onde animais costumam refugiar-se - não no deserto árido e sem vida, mas próximos de caminhos, árvores e grutas, especialmente no fundo de vales, matas ciliares e de encostas. Smith (1995, p. 124) identificou os locais onde a vida natural é mais ativa como provável fonte de sinais e sons noturnos que amedrontavam caçadores e 
viajantes em regiões assombradas do Saara. O orientalista adverte, porém, que uma explanação tão geral como essa não explica tudo. De modo análogo, se tal hipótese não esclarece os "misteriosos roncos de um avião fantasma", ela aplicar-se-ia aos excertos dos contos "O Cara de Fogo" e "João perdido", de Jayme Griz:

A Volta dos Bambus, onde a estrada de ferro fazia uma curva, num corte cavado numa pequena elevação do terreno, era lugar ermo e malassombrado, dizia o povo. Ninguém gostava de passar ali sozinho, de noite ou mesmo de dia. Havia quem tivesse ouvido ali passos sobre a folhagem que forra o chão e abafados e prolongados gemidos de almas penadas... Era esta a tradição daquele ermo e sombrio lugar. (GRIZ, 1969, p. 53-54).

Naquele momento um mistério insondável envolvia o mundo e as criaturas de Deus. A mata era àquela hora um mundo misterioso, sombrio e inescrutável, onde seres de sonho, de fábula e de lenda, se movimentavam embuçados nas trevas, havia milênios! (GRIZ, 1969, p. 116).

Embora ameaçadoras, florestas podem apresentar-se sob uma luz favorável, como fonte de beleza, exotismo, proteção e restauração (TUAN, 2013, p. 74). A literatura romântica expôs os dois extremos, o sublime e o sinistro, unindo-os na atração do belo, tornado fonte de perdição e ruína. Usual nos mitos e contos maravilhosos, tal aspecto foi absorvido pelo gênero fantástico.

Espaços sobrenaturais sempre inspiraram considerações teóricas e fascinação cultural. $\mathrm{O}$ mercado editorial e a indústria do entretenimento exploraram igualmente o apelo popular dos espaços misteriosos. A cultura popular e a literatura oferecem várias interpretações dos lugares mal-assombrados. Freyre e Nava apoiaram-se na tradição oral, na historiografia e outras formas de expressão cultural para narrar histórias de fantasmas que denotam as ambivalentes relações entre o homem e a paisagem. Quanto à obra de Griz, é provável que suas pesquisas folclóricas tenham influenciado O lobisomem da porteira velha (1956) e O Cara de Fogo (1969).

\section{Espaço, história e narrativa}

Ao explicar como a ficção atuaria na forma de palimpsesto, reclamando uma relação contínua com a história (no caso, a escravidão) e certa estrutura narrativa específica, Gordon (1997, p. 146) indaga se atualmente algumas obras poderiam ser lidas na acepção de uma sociologia popular. Logo, considerando a possibilidade dos contos de Griz em $O$ lobisomem da porteira velha e $O$ Cara de Fogo basearem-se em memorates, 
os relatos de Assombrações do Recife Velho ajustar-se-iam à ponderação de seu autor sobre o escritor conterrâneo: 6

Em O Lobisomem da Porteira Velha o escritor Jayme Griz reúne um grupo de histórias do melhor sabor regional, várias delas das chamadas de almas-do-outro-mundo. Gênero que eu próprio venho procurando desenvolver dentro dos meus limites e à margem dos estudos da minha predileção - antropologia do brasileiro - inspirado no que a tradição recifense guarda de mais especificamente urbano com relação ao sobrenatural. (FREYRE, 1955).

Segundo Gordon (1997, p. 146), na literatura americana sobre a escravidão, os relatos transcritos pelo compilador "branco" adotam convenções particulares, estilos, motivos e tropos que os inscrevem na literatura autobiográfica. Essa transcrição envolve questões implicadas na reinvenção individual e coletiva de certos discursos, como o da escravidão, e a tentativa de restauração espacial e temporal de um objeto em sua historicidade, na intenção de evocar uma pessoa em vez de um "sombrio" ideal (SPILLERS, 1989, p. 29 apud GORDON, 1997, p. 150, ênfase do autor). De forma análoga, nas passagens em que Freyre, Griz e Nava reconstituem, com base em fontes de primeira ou segunda mão, o espaço de "almas-do-outro-mundo":

Pode-se até especificar esta combinação de espaço com tempo para "rendez-vous" dos vivos com mortos, da gente sã com a que de doentiamente amarela se encanta às vezes em lobisomem: porteira de engenho, sexta-feira, meia-noite de noite escura - sinistramente escura. (FREYRE, 1955).

Em “O Cara de Fogo" e "João perdido", a ação decorre da situação de alguém que se afasta de um domínio conhecido, seguro, e percorre uma região inóspita durante a noite:

Com o seu velho lampião de querosene à mão, o barraqueiro transpôs as ruas desertas da cidade, atingiu a Estação da estrada de ferro, aí galgou a linha férrea e pôs-se a andar, vagarosa e cautelosamente, rumo â volta dos Bambus, de onde, lá chegando, tomaria, à esquerda, a vereda que o levaria até seu sítio. (GRIZ, 1969, p. 55).

Respectivamente, os contos aludem à região de Custódia, no sertão de Pernambuco e às matas do Mearim, no Maranhão. Vivendo no campo e trabalhando na

\footnotetext{
6 A folclorista Linda Dégh, em Legend and Belief: Dialectics of a Folklore Genre (2001) expôs a complexidade do processo de incorporação de características poéticas e literárias a memorates e fabulates.
} 
cidade, os protagonistas de ambas as narrativas são advertidos pela tradição oral local sobre os perigos de tais espaços:

Ia à caça. E ia dormir na mata (...) Apesar de ser um dia ruim de caça, sexta-feira, dia de caipora andar solta na mata, de dar surra em cachorro e atrapalhar caçador com seus assobios e estrepolias, e até fazer malassombrado e botar muito cabra mole para correr, mesmo assim Mané Bento foi p'ro mato. (...) De candeeiro aceso à mão (...) caminhava Bento no rumo do seu Jirau. (GRIZ, 1969, p. 113-114).

Alguns contos de O Cara de Fogo assumem a forma de diálogo entre dois transmissores, o da cultura oral e o da cultura erudita, este último ouvinte curioso supostamente letrado, cuja voz mediadora aparece em segundo plano, a exemplo de "O fantasma negro do bueiro da usina Cucaú”. “Assombração no Rio Formoso” reproduz o cenário do narrador na taverna, descrito por Geoffrey Chaucer e Álvares de Azevedo. A ficção pode recontar histórias e eventos que não estão mais restritos às testemunhas diretas ou ao contador de histórias e sua audiência. Assim, conforme Gordon (1997, p. 163), eventos são transmitidos, reimaginados por diferentes convenções que se estendem à interpretação atribuída pelo escritor às noções de espaço e lugar:

Na literatura de ficção, que tenta apreender a evolução comum da experiência humana, o espaço mantém uma relação dialética com o lugar: o espaço é oposto ao lugar, como o disforme é oposto ao formado. O lugar é um espaço estruturado. A palavra "espaço" é, então, quase que uma parte da experiência ocidental. (...) Lugar é qualquer localidade que tem significado para uma pessoa ou grupo de pessoas. (TUAN, 2011, p. 5).

Um relato sucede não por simples descrição ou explanação, mas como algo mais. Este algo mais equivale, na história de fantasmas, ao encantamento de "knowing the things behind things", conforme definiu Toni Morrison (1987, p. 37 in GORDON, 1997, p. 164, ênfase da autora). Narrando o apogeu e declínio de engenhos arcaicos, extintos por usinas modernas, os "antigos do lugar", descendentes de escravos, moradores e negociantes locais, transmitem por memórias o significado de paisagens já inexistentes, ou em ruínas: "A grandeza das casas-grandes nas terras de plantio e dos sobrados do Rio Formoso, com o tempo se acabou" (GRIZ, 1969, p. 167). Freyre expôs o contexto que se aplicaria aos protagonistas de $O$ Cara de Fogo:

O lavrador, o senhor de pequeno engenho, o fornecedor de cana de outrora, que precisasse de deixar suas terras agrestes para fazer qualquer 
negócio no Recife, que se acautelasse não só contra os espertos, os trapaceiros (...) como também contra os assombros. (FREYRE, 1987, p. 61)

Roderick Nash (1967; 1982), Tuan (1979; 2013) e Bernice Murphy (2013) discutiram a reação do colonizador europeu à paisagem do Novo Mundo e o impacto cultural de tal visão nas populações em formação. Nesse prisma, florestas corresponderiam ao caos, mistério e perigo, parte de um mundo selvagem, habitado por seres incompatíveis com a noção de civilização, apesar da beleza e riqueza potenciais. Estar perdido em uma floresta, território que as leis da civilização não alcançam nem controlam, é um dos motivos essenciais (com inúmeras variantes) dos contos de fadas e histórias da cultura popular. Campos cultivados são atribuídos a um mundo familiar, harmonioso e organizado. Em contraste, as florestas circundantes ofereceriam morada ao que é arriscado, desconhecido e estranho (Murphy, 2013, p. 20).

“O espaço não é uma ideia, é um conjunto complexo de ideias”, afirmou Tuan (2011, p. 5). Nas histórias de fantasmas, o espaço também pode ser considerado um sistema heterogêneo. Para Gordon (1997, p. 151), o significado dos fantasmas em certa cultura, incluindo o reflexo artístico e literário da tradição, deve parte de sua origem ao respectivo lugar ocupado por esses mesmos fantasmas no cotidiano e no pensamento de uma geração. Em Baú de ossos, Nava (1974, p. 103) vincula uma fauna e flora sobrenaturais a relatos oriundos “[...] do Curral, do Sabará, de Nova Lima, Caeté, Santa Luzia, Itabira, Cocaes, Santa Bárbara, Mariana, Ouro Preto, Congonhas do Campo. Terras pesadas de espantos e metais. Noruegas cheias de avencas e assombrações”, espaços de “entes fora-de-portas. Mitos rústicos e não urbanos” (Freyre, 1987, p. 50). Recorde-se que um dos princípios fixados em Assombrações do Recife Velho consiste em distinguir as relações do mundo material, cotidiano, com os seres do mundo invisível:

Também estas pertencem à história sobrenatural do Recife e não apenas à natural. (...) É assim a história sobrenatural do Recife rica em manifestações de uma diversidade que aos viciados em interpretar a história dos homens ou dos povos por métodos predominantemente naturalistas recorda o fato de ser a velha cidade brasileira do Norte uma das que maior número de influências contraditórias - europeias, africanas, indígenas - têm reunido; e vêm harmonizando. (FREYRE, 1987, p. 54-55). 
O relato a seguir concerne às memórias de infância de Nava, entre o Rio de Janeiro e Juiz de Fora, destacando-se pelo caráter insólito que a assombração ocupa na paisagem hostil:

O Osório era copeiro em casa de meu Pai e sua irmã Emilieta, cria de minha avó materna. Quando eram meninos, no Piauí, tinham de atravessar a mata para chegar à escola. Na hora do meio-dia (tão assombrada como a da meia-noite!), eles passavam debaixo da jaqueira que ramalhava toda no ar sem vento, estalava os galhos como braços espreguiçando e nunca deixava de perguntar: "Já vai?" Assim como quem dissesse - para quê? para onde vamos, nem precisa ir porque certo, certo, é que lá chegamos... (NAVA, 1974, p. 106-7).

Segundo Bell (1997), a linguagem cultural da modernidade, diversamente da utilizada na ficção, lenda e mito, mostraria certa prevenção ante o discurso sobre a presença de fantasmas. Porém lugares podem ser referidos de acordo com os fantasmas que os habitam. O significado de um lugar, seu genius loci, depende da classe de espíritos (Bell, 1997, p. 813) ou da natureza do jinn que o frequenta (Smith, 1995, p. 123). Tuan complementa tal reflexão, observando que:

A tendência comum no pensamento pré-moderno, no entanto, é a de afastar-se do caráter abstrato do espaço para o caráter concreto do lugar. O espaço mítico, plenamente desenvolvido, é mais precisamente descrito como lugar mítico. No pensamento mitológico, norte, sul, leste e oeste não possuem tanto o sentido de "direção", mas de localidades bem conhecidas onde os poderes da natureza residem. (TUAN, 2011, p. 5).

Para chegar à escola, Osório e Emilieta "tinham de atravessar a mata", uma das "localidades bem conhecidas onde os poderes da natureza residem", sobretudo nas histórias em que o maravilhoso e o sobrenatural desafiam as leis naturais, feito a "da jaqueira que ramalhava toda no ar sem vento". O caráter geral da crença em árvores falantes foi estudado por Alexander Porteous, em The Lore of the Forest: Myths and Legends (1928) e Angelo Solomon Rappoport, em The Folklore of the Jews (1937).

Câmara Cascudo fez um resumo teórico desta crença:

Toda a Europa e a África estão cheias de árvores que se vingam, choram e têm história local. (...) Umas vibram toda a folharia rumorejante, como se soprasse um pé-de-vento impetuoso, e não há a menor aragem. Há iluminação misteriosa, vozes, músicas, ao redor de certas árvores (...) Também a tradição guarda a memória de árvores que se locomovem durante a noite, voltando ao pouso primitivo, ao alvorecer. (CASCUDO, 1993, p. 109-111). 
Sobre a floresta como espaço mítico, o folclore e a literatura revelam-se extensos. Em Banguê, obra de teor memorialístico, José Lins do Rego (1934, p. 131 apud CASCUDO, 1993, p, 111) escreve: "Estava bem perto das cajazeiras mal-assombradas. Diziam que elas mudavam de lugar à meia-noite. Fiz carreira para atravessar o escuro". Nos relatos de Nava e José Lins, tempo e espaço míticos não se dissociam: a "hora do meio-dia (tão assombrada como a da meia-noite!)", configurando o espaço por relação metonímica: "debaixo da jaqueira que ramalhava toda no ar sem vento" e "perto das cajazeiras mal-assombradas". Segundo o registro de Freyre:

De árvores mágicas também se encontram traços na história sobrenatural do Recife. Uma delas, certa gameleira antiga do Fundão, no sítio do velho babalorixá já morto Pai Adão (...). Dizem que era pela gameleira mágica que se comunicava com a Mãe África, ouvindo vozes que lhe diziam em nagô: "Adão, faça isso", "Adão, faça aquilo". Bem diferente, essa gameleira grave e matriarcal da jaqueira meio burlesca - quase de fita cômica de cinema americano - que outro meu amigo, Paulo Rangel Moreira, conheceu menino em engenho do Sul de Pernambuco e cuja fama chegou até ao Recife: jaqueira donde dizia a gente do povo que se desprendiam jacas mal-assombradas de picos um tanto parecidos com espinhos de ouriço-cacheira. Corriam atrás das pessoas como se fossem bichos enraivecidos. Principalmente atrás de meninos. (FREYRE, 1987, p. 54)

Para Tuan (1979), o medo do mundo natural atenua-se uma vez estendido o poder do homem sobre a natureza e controladas as ameaças e restrições do ambiente - o mundo urbano efetivamente resiste às flutuações da natureza. Eventos excepcionais, como catástrofes naturais, podem devastar cidades, mas o medo difere daquele conhecido no passado, pois as forças naturais já não são encaradas como malignas, ou seja, imbuídas do desejo de destruir. Paradoxalmente, é na cidade, símbolo mais evidente do triunfo da racionalidade sobre a natureza, que residem alguns dos velhos medos. O caos desorientador da expansão urbana e o estado de alarme dos habitantes remetem à ideia de selva. Mas a maior ameaça na cidade ainda são as outras pessoas. Nesse sentido, Freyre cita uma personalidade histórica transformada em "mito de terror", expondo como a memória é percebida pela população local através do tempo:

Cabeleira, o bandido dos canaviais, veio, certa vez, ele próprio, em pessoa, com toda a sua ira de monstro, até as pontes do Recife, ao próprio centro da cidade ilustre, assombrando recifenses até então acostumados a incursões de piratas ou de corsários estrangeiros, saídos 
do mar, mas não a ser assaltada por demônios vindos do próprio interior da região. (...) Cabeleira subsistiu para os recifenses como assombração até quase nossos dias. (FREYRE, 1987, p. 59-60).

Se Tuan (1979) expôs a ideia de ameaça partilhada como fator de unificação para um grupo, John W. Handmer e Stephen Dovers (2007, p. 71) notaram que a proteção contra perigos humanos e naturais foi uma das razões para a criação de vilas e cidades, mas não a única: dividir interesses e oportunidades gerou o apoio mútuo entre comunidades modernas diante de ameaças e problemas comuns, a exemplo de riscos ambientais e recuperação de catástrofes naturais.

Ao recordar um fato, histórias de fantasmas podem encerrar mensagens que não foram oficialmente sancionadas. É possível afirmar que, se uma aparição sobrenatural de certo modo interdita determinado espaço, ao mesmo tempo pode afastar do anonimato locais e pessoas antes despercebidos pela sociedade, tornando-os memoráveis pela transmissão de uma história. Entes sobrenaturais são forças intangíveis mas capazes de afetar seres e espaços concretos nos relatos de Freyre, Griz e Nava. Relatos de Freyre, como "O vulto do salão nobre" e "O Santa Isabel do Recife: suas assombrações"; "A enforcada da mata do Chareta" e "O fantasma negro do bueiro da usina Cucaú", de Griz, sugerem que a alma do morto não representa somente a personalidade do indivíduo, mas se converte, sobretudo, no espectro de um momento da história de um lugar.

\section{Considerações finais}

Ao recontar memórias de experiências sobrenaturais coligidas "para o velho jornal A província, do Recife", Gilberto Freyre sugere ter adotado enfoque literário, sem excluir a visão do sociólogo. Em prefácio à primeira edição de Assombrações do Recife Velho, ele arguiu que o escritor pode ressaltar a contribuição entre áreas diversas, dissipando aparentes contradições:

Quem se surpreender com um livro sobre assombrações, de escritor que tem na Sociologia (como outros na Medicina ou na Engenharia) seu mais constante ponto de apoio - embora seja principalmente escritor e não sociólogo - que contenha sua surpresa ou modere seu espanto. Pois não há contradição radical entre sociologia e história, mesmo quando a história deixa de ser de revoluções para tornar-se de assombrações. (FREYRE, 1987, p. 25). 
Em Assombrações do Recife Velho e O Cara de Fogo há passagens que relacionam o espaço mal-assombrado ao lugar "[...] onde em vida morou seu velho senhor, e onde, depois de morto, ainda morava ele, como fantasma" (GRIZ, 1969, p. 170). Ao compilar os relatos, Freyre observa o viés histórico, "segundo os cronistas da cidade" do Recife, como Maria Graham, Sebastião Galvão, Franklin Távora e Pereira da Costa, mas referindo, como William Robertson Smith (1995, p. 120-124), a participação do mundo natural no que se julga inexplicável:

A verdade porém é que o choro era quase sempre de menino doente. (...) Às vezes nem disso era o choro parecido com o de menino, mas de cururu ou de outro sapo tristonho, e com a fama de bicho de bruxo, em algum capinzal de beira de lagoa ou de rio, nas noites úmidas do Recife. Talvez tenha vindo daí o nome de Chora-Menino que por tanto tempo foi o de um descampado da cidade, afinal chamado oficialmente por outro nome. Não nos deixemos porém arrastar pela tentação de reduzir a história natural a história do Recife. Pois neste ponto a tradição é de que naquele descampado houve matança e sepultamento de recifenses, inclusive de meninos ou inocentes, numa das agitações que ensanguentaram o velho burgo. Pelo que durante anos o largo inteiro teria ficado mal-assombrado com o choro dos inocentes. "Uma lenda semelhante a outras muitas criadas pela imaginação popular para explicar certos fatos anda ligada à denominação atual de 'ChoraMenino"”, escreveu sisudamente no princípio deste século o historiador Sebastião Galvão. (FREYRE, 1987, p. 37).

Mas nem toda lenda e relato de fantasmas tem a função de reparo emocional, vinculando lugares a contextos históricos específicos. Memórias individuais ajudam a criar a memória coletiva, que resiste ou segue a variação da paisagem, por reurbanização ou pelo abandono que faz de ruínas paisagens reconfiguradas, destituídas de conexão social e sentido pragmático. Para Edensor (2005a), além de morada de fantasmas e desabrigados, ruínas são campo de pesquisa para memórias do passado; santuários ecológicos para espécies cujo habitat foi destruído; e cenários interpretados artisticamente pelo cinema, escultura, fotografia, literatura e pintura.

No século XIX, a iluminação das cidades teria afugentado os fantasmas, segundo Freyre (1987, p. 46): “[...] não só das ruas como do interior das casas. Obrigando-os a se refugiarem nos ermos, nos cemitérios, nas ruínas, nos restos de igrejas, de conventos, de fortalezas, nos casarões abandonados, nas estradas tão sombreadas de arvoredo". Griz (1969, p. 28) sintetiza essa transformação ressaltando o isolamento por interdição de algumas áreas: "Diante do acontecido, o senhor do engenho mandou derrubar a porteira do sítio malassombrado e no seu lugar foi levantada uma cerca. E desse dia em diante 
ninguém mais passou ali. E o sítio da Conha virou mata". Também na cidade moderna, assinalou Edensor (2005b, p. 833), há lugares assombrados pelo que foi segregado, esquecido ou negligenciado, e onde a memória não pode ser inteiramente silenciada: "Um cunhado do Dr. Bernardino (...) a qualquer hora do dia ou da noite, estivesse sozinho ou acompanhado, se passasse perto de cemitério era logo chamado pela algazarra dos defuntos: 'Franzen! Franzen! Franzen!’” (NAVA, 1974, p. 106).

As histórias de fantasmas de Assombrações do Recife Velho, O Cara de Fogo e Baú de Ossos contribuem para uma sociologia da memória ao apresentar resquícios do passado que revelam, literariamente, memórias de espaços afetados por processos de um mundo em transição: iluminação de cidades, industrialização, mecanização do setor agrícola, migrações, transformações culturais, ecológicas, econômicas, geográficas e sociais que alteram costumes, ritmo de trabalho, lazer e percepção do tempo e do espaço. Do ponto de vista histórico, espaço e memória coletiva admitiriam influência mútua na interpretação do passado e presente:

\footnotetext{
Quando uma assombração cíclica aparece é que a casa (...) vai sofrer morte ou desgraça. Ou então outra experiência que lhe revolucionará a vida, não só para pior como para melhor. Ou num e noutro sentido como é próprio dos acontecimentos que revolucionam a vida dos homens. Um especialista no assunto, A. T. Baird (...) chama de "assombração premonitora" aquela que anuncia morte, desgraça ou revolução, lembrando que estão nesse caso várias aparições por que se têm tornado famosos alguns dos velhos castelos da Europa. (FREYRE, 1987, p. 117).
}

Historiografia, literatura e cultura popular têm modos particulares de registrar e atribuir sentido à memória, oferecendo novas formas de idealização do espaço. Para Gordon (1997, p. 178), histórias de fantasmas seriam histórias de ausências. Por extensão, lugares mal-assombrados, tomando de empréstimo o termo à Semiótica, teriam o valor de índice na natureza do processo de reconhecimento dessa ausência. Na Era vitoriana, a fotografia esmerava-se em criar fotos de fantasmas, posicionando, em primeiro plano, vivos e mortos lado a lado. Hoje, o efeito de verossimilhança é obtido com a suposta imagem sobrenatural pouco destacada na paisagem, quase sempre ao fundo, como se captada por acaso pelo fotógrafo, ou seja, outrora a aparição era o fantasma de alguém, agora seria, a priori, um fantasma do ambiente. A imagem fantasmagórica, "despercebida" ao autor no instante da foto, mais tarde revela sua história e a do lugar, expondo curiosas relações entre espaço, evidência histórica e fenômeno cultural. Nos 
relatos expostos em Assombrações do Recife Velho, O Cara de Fogo e Baú de Ossos, o enfoque nos espaços "mal-assombrados" sugere que a forma de recordar também muda com o tempo.

\section{Referências}

BELL, M. M. The Ghosts of Place. Theory and Society, n, 26, v. 6, p. 813-836, 1997. Disponível em: http://dces.wisc.edu/wp-content/uploads/sites/30/2013/08/bell-1997ghosts.pdf. Acesso em: 08/02/2019.

BROWN, P. Society and Supernatural: A Medieval Change. Daedalus, V. 104, n. ${ }^{\circ}$ 2, p. 133-151, Spring, 1975.Disponível em: https://www.jstor.org/stable/20024334?seq=1. Acesso em: 02/10/2020.

CASCUDO, L. C. Dicionário do Folclore Brasileiro. Rio de Janeiro: Ediouro, 1993.

CZARNIAWSKA, B. Narratives in Social Science Research. London: Sage Publications, 2004.

EDENSOR, T. Industrial Ruins: Space, Aesthetics and Materiality. Oxford: Berg, 2005a.

EDENSOR, T. The Ghosts of Industrial Ruins: Ordering and Disordering Memory in Excessive Space. Environment and Planning D. Society and Space, v. 23, n. 6, p. 829849, 2005b. Disponível em: https://www.researchgate.net/...Ghosts_of_Industrial_Ruins_Order. Acesso em: 19/01/2019.

FREYRE, G. Assombrações do Recife Velho. Rio de Janeiro: Record, 1987.

FREYRE, G. Lobisomens. O Jornal. Rio de Janeiro, 21de agosto de 1955. Disponível em:

docvirt.com/docreader.net/WebIndex/WIPagina/Tematico/34053. Acesso em: 08/02/2019.

GORDON, A. Ghostly Matters: Haunting and the Sociological Imagination. Minneapolis: University of Minnesota, 1997.

GRIZ, J. O Cara de Fogo. Recife: Museu do Açúcar, 1969.

KUHNE, D. African Settings in Contemporary American Novels. Westport, Connecticut, London: Greenwood Press, 1999.

LOWRY, T. The Last Sleep: The Battle of Droop Mountain, November 6, 1863. Charleston, WV: Pictorial Histories Publishing Co., 1996.

MAHOUDEAU, A. Space in Social Movement Studies: a literature review. The Cobble and the Frame: Sociology of mobilizations and geographical imagination, 2016. Disponível em: https://tcatf.hypotheses.org/30. Acesso em: 19/01/2019.

MEDEIROS, R. A aviação pioneira nos céus potiguares: dos primeiros raids ao início da aviação comercial. Tok de História. Arquivo da tag: Paris-Amérique-Latine, 2014. Disponível em: https://tokdehistoria.com.br/tag/paris-amerique-latine/. Acesso em: 19/01/2019. 
MOUTINHO, J. G. N. Prefácio de J. G. Nogueira Moutinho. In: FREYRE, G. Assombrações do Recife Velho. Rio de Janeiro: Record, 1987, p. 19-24.

MURPHY, B. M. The Rural Gothic in American Popular Culture: Backwoods Horror and Terror in the Wilderness. Basingstoke: Palgrave Macmillan, 2013.

NAVA, P. Balão Cativo. Rio de Janeiro: Livraria José Olympio Editora, 1977.

NAVA, P. Baú de Ossos. Rio de Janeiro: Livraria José Olympio Editora, 1974.

NAVA, P. Chão de Ferro. Rio de Janeiro: Livraria José Olympio Editora, 1976.

SMITH, W. R. Lectures of the Religion of the Semites. Sheffield: Sheffield Academic Press, 1995.

SOBRINHO, B. J. Signs, Solidarities, and Sociology: Charles S. Peirce and the Pragmatics of Globalization. Maryland: Rowman \& Littlefield Publishers, 2001.

SUZZONI, J. P. s/d. Un exploit aéronautique injustement oublié: Le lieutenant Pierre de Saint Roman à la conquête de l'Atlantique sud. Association de Recherches Baziégeoise: Racines et Environnement. Disponível em: http://arbrebaz.free.fr/Documents/St_Roman/Pierre_St_Roman.html. Acesso em: $12 / 06 / 2017$.

TAUNAY, A. E.; TAUNAY, A. E. O Grande Imperador. São Paulo: Cia. Melhoramentos de São Paulo, 1932.

THOMPSON, S. The Folktale. Berkeley: University of California Press, 1977.

TUAN, Y. F. Espaço, tempo, lugar: um arcabouço humano. Geograficidade, Niterói, v. 1, n. 1, p. 4-12, 2011.

TUAN, Y. F. Landscapes of Fear. New York: Pantheon Books, 1979.

TUAN, Y. F. Romantic Geography. In: Search of the Sublime Landscape. Madson, Wiscosin: The University of Wiscosin Press, 2013.

VAUGHAN, T. Fact and Fiction in a Legend. Folklore, London, v. 119, n. 2, p. 218-232, 2008.

Disponível

em:

https://www.researchgate.net/publication/249014405_Fact_and_Fiction_in_a_Legend.

Acesso em: 19/01/2019.

Data de Recebimento: 07/07/2019

Data de Aprovação: 31/10/2020 


\section{Para citar essa obra:}

GABRIEL, Maria Alice Ribeiro A memorialística do espaço em Gilberto Freyre, Jayme Griz e Pedro Nava. In: RUA [online]. Volume 26, número 2 - p. 729-756 - eISSN 2179-9911 - Novembro/2020. Consultada no Portal Labeurb - Revista do Laboratório de Estudos Urbanos do Núcleo de Desenvolvimento da Criatividade. http://www.labeurb.unicamp.br/rua/

Capa: O antigo Solar de Megaípe - Fonte: Wikipédia

Laboratório de Estudos Urbanos - LABEURB

Núcleo de Desenvolvimento da Criatividade - NUDECRI

Universidade Estadual de Campinas - UNICAMP

http://www.labeurb.unicamp.br/

Endereço:

LABEURB - LABORATÓRIO DE ESTUDOS URBANOS

UNICAMP/COCEN / NUDECRI

CAIXA POSTAL 6166

Campinas/SP - Brasil

CEP 13083-892

Fone/ Fax: (19) 3521-7900

Contato: http://www.labeurb.unicamp.br/contato 